\title{
Reproductive cycles of four species of Patella (Mollusca: Gastropoda) on the northern and central Portuguese coast
}

\author{
PEDRO A. RIBEIRO ${ }^{1,2,3}$, RAQUEL XAVIER ${ }^{1}$, ANTÓNIO M. SANTOS ${ }^{1,4}$ AND STEPHEN J. HAWKINS ${ }^{2,3,5}$ \\ ${ }^{1}$ CIBIO, Centro de Investigação em Biodiversidade e Recursos Genéticos, Campus Agrário de Vairão, 4485-661 Vairão, Portugal, \\ ${ }^{2}$ Marine Biological Association of the United Kingdom, Plymouth, UK, ${ }^{3}$ School of Biological Sciences, University of Southampton, \\ Southampton, UK, ${ }^{4}$ Departamento de Zoologia-Antropologia, Faculdade de Ciências da Universidade do Porto, 4099-002 Porto, \\ Portugal, ${ }^{5}$ School of Ocean Sciences, Menai Bridge, Bangor University, Bangor, Gwynedd, UK
}

\begin{abstract}
The reproductive cycles of four limpet species, Patella depressa, Patella ulyssiponensis, Patella vulgata and Patella rustica are described for several locations in northern and central Portugal. Patella depressa and P. ulyssiponensis displayed almost continual gonad activity, with two main spawning periods, September-January and March-June, and minor spawning events dispersed throughout the year. Patella vulgata and P. rustica exhibited highly synchronized reproductive cycles, with welldefined breeding and resting periods. Gonad development in P. vulgata started in September and spawning took place from November-December to March. In P. rustica development started in June and spawning occurred from SeptemberOctober to December-January. Compared to the 1980s these results suggest that breeding periods are becoming longer in southern species and shorter in northern species.
\end{abstract}

Keywords: limpet, Patella depressa, Patella ulyssiponensis, Patella vulgata, Patella rustica, reproductive cycles, Portugal

Submitted 9 June 2008; accepted 16 December 2008; first published online 15 April 2009

\section{INTRODUCTION}

Annual reproductive cycles and the underlying triggers for gonad development and spawning in limpets have been extensively investigated over many years (Orton et al., 1956) for several species (Branch, 1981). Reproductive cycles of Patella in the north-eastern Atlantic region are particularly well known in the British Isles for Patella vulgata Linnaeus, 1758 (e.g. Orton et al., 1956; Thompson, 1980; Bowman \& Lewis, 1986; Delany et al., 2002), but also for Patella depressa Pennant, 1777 (Orton \& Southward, 1961; Moore et al., 2007) and Patella ulyssiponensis Gmelin, 1791 (Evans, 1953; Thompson, 1979; McCarthy et al., 2008). To a lesser extent, northern France (Fisher-Piètte, 1948; Choquet, 1966) and Spain (Othaitz, 1994) have also been covered. In contrast, reports on the reproductive cycles of Patella for Portugal are scarce, other than those by Guerra \& Gaudêncio (1986) encompassing the entire Portuguese coast (at three locations) for $P$. vulgata, $P$. depressa and $P$. ulyssiponensis and Brazão et al. (2003), for $P$. depressa at two adjacent locations in central Portugal. Moreover, no published studies are available for Patella rustica Linnaeus, 1758. This warm-water species was until recently absent from northern Portugal, and is currently colonizing this region (Lima et al., 2006). Establishing its spawning period in Portugal would contribute to a better understanding of the processes driving this expansion.

Corresponding author:

P.A. Ribeiro

Email: paribeir@fc.up.pt
This paper presents updated information on the reproductive cycles of the most common limpet species along the northern Portuguese coast, and also provides the first account of the reproductive cycle of $P$. rustica in Portugal. Comparisons are made with studies in Portugal during the 1980s, as well as further north in Europe to examine the influence of climate change.

\section{MATERIALS AND METHODS}

The reproductive cycles of Patella depressa, Patella ulyssiponensis and Patella vulgata were investigated at the northernmost part of the Portuguese coast, within an area encompassing about $100 \mathrm{~km}$ of coastline, where five rocky shores were selected for sampling: Moledo do Minho $\left(41^{\circ} 50^{\prime} \mathrm{N} 8^{\circ} 53^{\prime} \mathrm{W}\right)$, Viana do Castelo $\left(41^{\circ} 42^{\prime} \mathrm{N} 8{ }^{\circ} 52^{\prime} \mathrm{W}\right)$, Cabo do Mundo $\left(41^{\circ} 13^{\prime} \mathrm{N}\right.$ $\left.8^{\circ} 44^{\prime} \mathrm{W}\right)$, Homem do Leme $\left(41^{\circ} 09^{\prime} \mathrm{N} 8^{\circ} 42^{\prime} \mathrm{W}\right)$ and Aguda $\left(41^{\circ} \mathrm{O}^{\prime} \mathrm{N} 8^{\circ} 40^{\prime} \mathrm{W}\right)$. Samples were taken monthly, between December 1997 and January 2001 for P. depressa and $P$. ulyssiponensis and between January 1999 and March 2001 in the case of $P$. vulgata. Samples of $P$. depressa were obtained from all five sites, whereas $P$. ulyssiponensis was collected from Moledo do Minho, Cabo do Mundo and Aguda and P. vulgata from Moledo do Minho, Viana do Castelo and Homem do Leme. Monthly samples of $P$. rustica were collected between October 2005 and October 2007 from Cabo Raso, located at the central Portuguese coast $\left(38^{\circ} 42^{\prime} \mathrm{N} 9^{\circ} 29^{\prime} \mathrm{W}\right)$, where their abundance was sufficient to enable regular collection of samples.

Samples of 30-50 individuals of each species were collected haphazardly in each shore, within size-ranges of $15-35 \mathrm{~mm}$ 
for $P$. depressa, 20-45 mm for P. ulyssiponensis and P. vulgata and $20-35 \mathrm{~mm}$ for $P$. rustica. All samples were stored in a $5 \%$ formalin-seawater solution until gonad examination in the laboratory. The sex of all specimens was determined and the maturity of gonads was macroscopically assessed and categorized according to the scale established by Orton et al. (1956) for P. vulgata. The reproductive cycle of each population was described by the monthly variation in the percentage of neuter or almost empty gonads (Stages o and 1) and in the percentage of full gonads (Stages 4 and 5). Spawning events were identified by a drop in the proportion of full gonads and a concomitant increase in the percentage of empty gonads.

Reproductive synchrony among sexes was investigated using standard correlation analyses (Pearson's correlation coefficient) on the proportion of gonads at an early development condition (Stage 1) and the proportion of mature gonads (Stages 4 and 5) for each location and species. Both variables were highly correlated among males and females (Pearson's $r: P<0.001$ at every location and for all species), and therefore, subsequent analyses were performed on
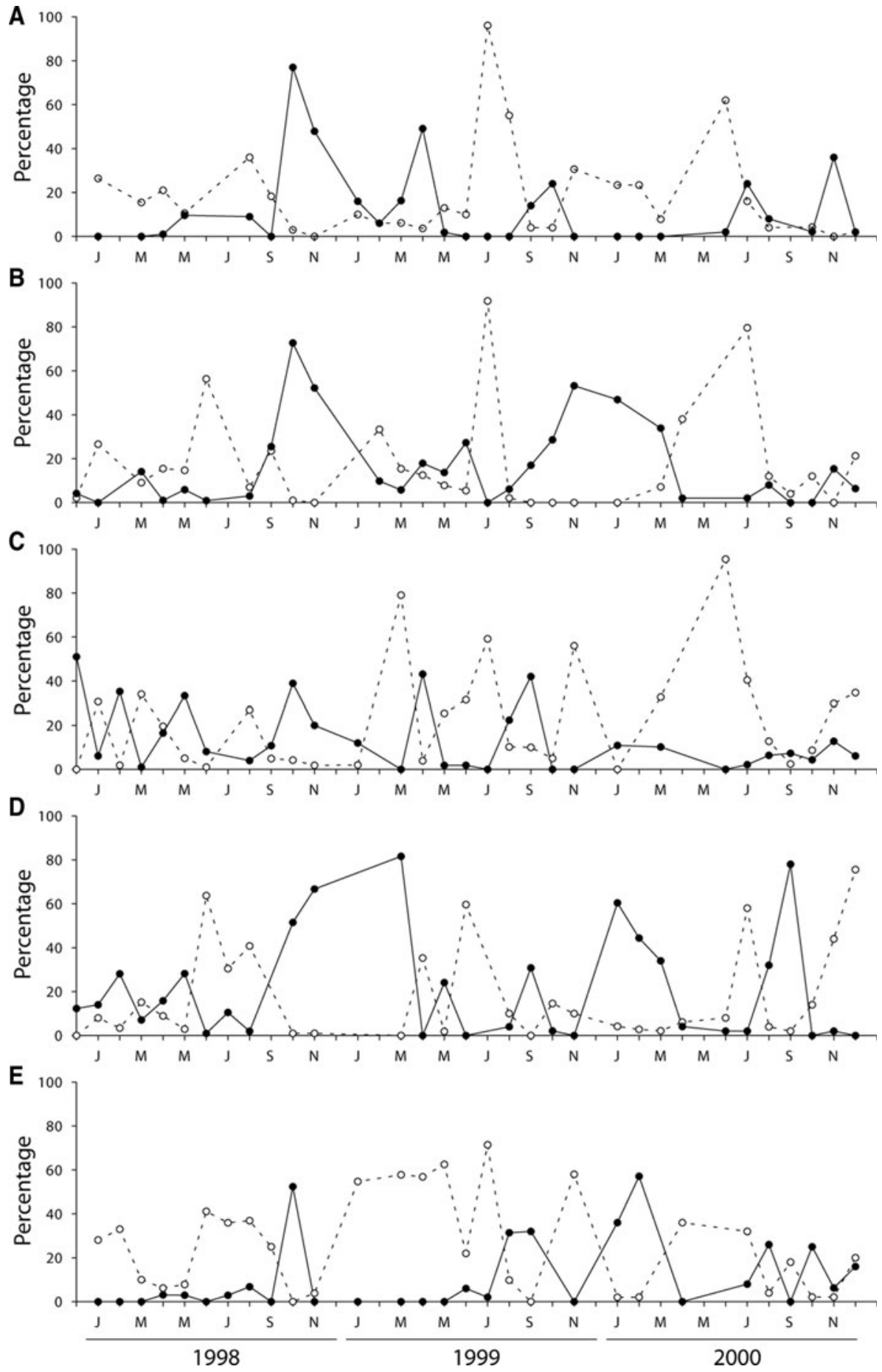

Fig. 1. Patella depressa: percentage of gonads in undeveloped (neuter or Stage 1, dashed line) and advanced (gonad Stages 4 and 5 , full line) maturation state, between December 1997 and December 200o, at (A) Moledo do Minho, (B) Viana do Castelo, (C) Cabo do Mundo, (D) Homem do Leme and (E) Aguda. 
pooled data. Correlation analysis was also used to test for synchronization among locations within each species, by calculating correlation matrices and testing the significance of correlation coefficients among each pair of locations.

\section{RESULTS}

The average male:female ratio within sites over the study period showed a predominance of females in samples of Patella ulyssiponensis (range 0.6:1 to 1.1:1), Patella vulgata (o.6:1 to 1.0:1) and Patella rustica (0.8:1), whilst in Patella depressa males were collected consistently in higher numbers than females (1.3:1 to 1.5:1).

The reproductive cycles of $P$. depressa and $P$. ulyssiponensis displayed similar annual patterns (Figures $1 \& 2$ ), with gonad development being observed throughout the year and considerable proportions of undeveloped gonads occurring mainly between May and July. It is clear that both species went through multiple spawning events within each study year. Main spawning periods typically took place between September and January, followed by gonad re-ripening with another major spawning event between March and June. There was, however, considerable variation around the basic reproductive pattern among years and locations, particularly in $P$. depressa, as confirmed by the lack of a significant correlation in levels of gonad development among most pairs of locations (Table 1). An example of the variability displayed by P. depressa could be seen at Aguda in 1999 (Figure 1E), with
$50-70 \%$ of the individuals remaining inactive from January to May, while in other locations this percentage was much lower. In $P$. ulyssiponensis, there was a significant correlation in the proportion of undeveloped gonads among all locations, but a weaker correlation was found when considering the proportion of ripe gonads (Table 2). In both species, results suggest that individuals within each population were poorly synchronized, since all stages of development were represented in the majority of monthly samples. Higher levels of within-population synchronization were observed during the partial early summer pause and the subsequent development period.

In contrast, $P$. vulgata (Figure 3 ) and $P$. rustica (Figure 4) displayed highly synchronized seasonal breeding cycles, with smaller variation in gonad development within most samples, as well as minimal year to year differences. In P. vulgata, a significant correlation in the proportions of undifferentiated and full gonads was found among sampling sites throughout the study period (Table 3). Gonad development took place between September and November, with spawning occurring almost immediately. Gonad condition declined very abruptly between November and January (with a corresponding increase in the proportion of neuter gonads), and by the end of March all individuals were in the resting condition. Gamete release took place during just one annual spawning event, except at Homem do Leme in September 1998, where there was evidence of a minor initial spawning before the main event in November. Gonad development in $P$. rustica also exhibited marked synchronism, with $100 \%$ of the sampled individuals remaining

A
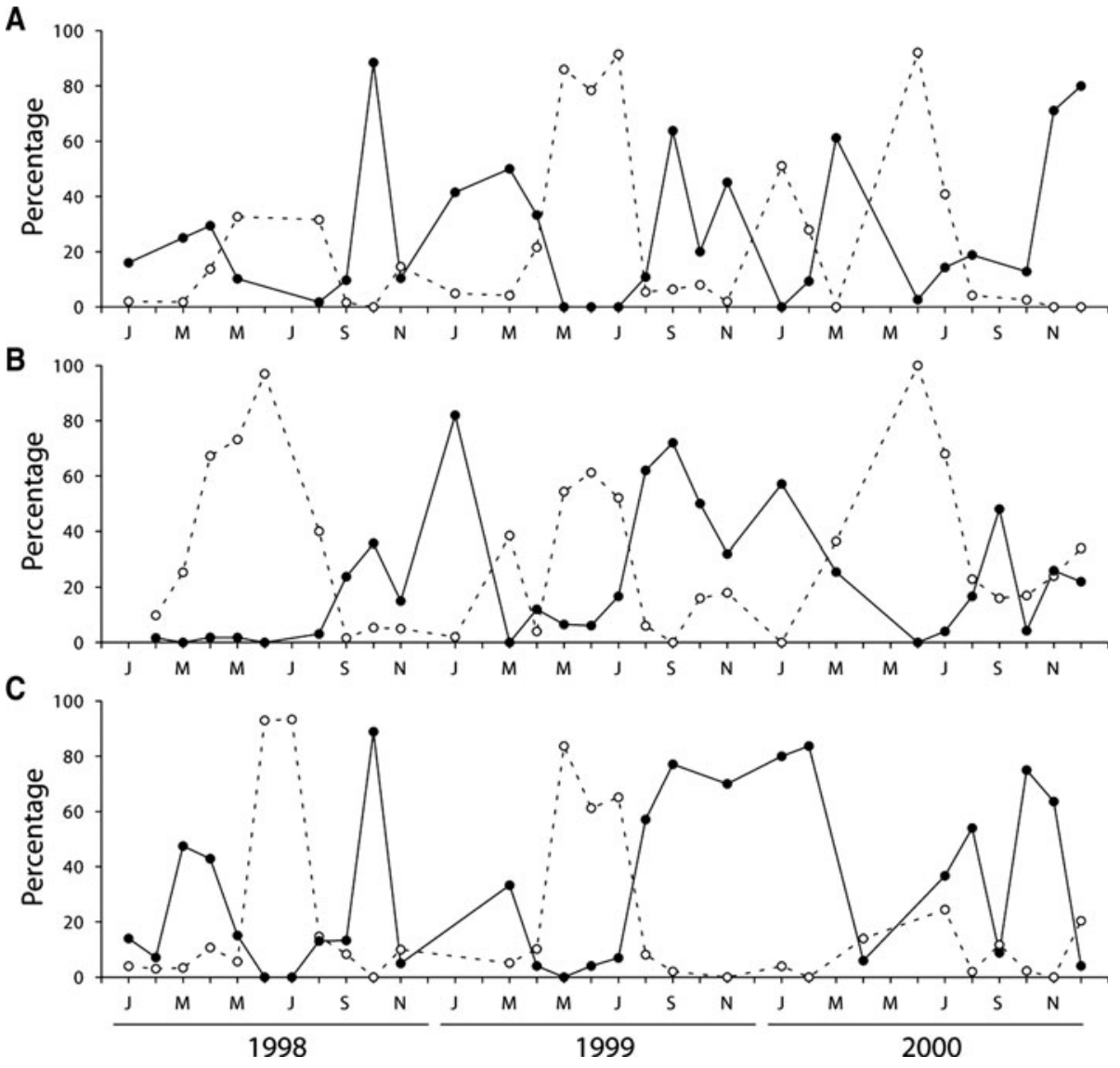

Fig. 2. Patella ulyssiponensis: percentage of gonads in undeveloped (neuter or Stage 1, dashed line) and advanced (gonad Stages 4 and 5 , full line) maturation state, between January 1998 and December 2000, at (A) Moledo do Minho, (B) Cabo do Mundo and (C) Aguda. 
Table 1. Patella depressa: Pearson's correlation coefficient $(r)$ among locations, using the proportion of undeveloped (neuters and Stage 1, below diagonal) and full gonads (Stages 4 and 5, above diagonal). Significant values are in bold.

\begin{tabular}{llllll}
\hline & $\begin{array}{l}\text { Moledo do } \\
\text { Minho }\end{array}$ & $\begin{array}{l}\text { Viana do } \\
\text { Castelo }\end{array}$ & $\begin{array}{l}\text { Cabo do } \\
\text { Mundo }\end{array}$ & $\begin{array}{l}\text { Homem do } \\
\text { Leme }\end{array}$ & Aguda \\
\hline $\begin{array}{c}\text { Moledo do } \\
\text { Minho }\end{array}$ & - & 0.491 & 0.583 & 0.283 & 0.106 \\
$\begin{array}{c}\text { Viana do } \\
\text { Castelo }\end{array}$ & 0.002 & - & 0.243 & 0.417 & 0.371 \\
$\begin{array}{c}\text { Cabo do } \\
\text { Mundo }\end{array}$ & 0.068 & 0.279 & - & 0.139 & 0.305 \\
$\begin{array}{c}\text { Homem do } \\
\text { Leme }\end{array}$ & 0.078 & 0.420 & 0.208 & - & 0.232 \\
$\begin{array}{c}\text { Aguda } \\
\text { Anda }\end{array}$ & 0.175 & 0.206 & 0.569 & 0.155 & - \\
\hline
\end{tabular}

Table 2. Patella ulyssiponensis: Pearson's correlation coefficient $(r)$ among locations, using the proportion of undeveloped (neuters and Stage 1 , below diagonal) and full gonads (Stages 4 and 5 , above diagonal). Significant values are in bold.

\begin{tabular}{llll}
\hline & Moledo do Minho & Cabo do Mundo & Aguda \\
\hline Moledo do Minho & - & 0.281 & 0.291 \\
Cabo do Mundo & $\mathbf{0 . 5 0 2}$ & - & 0.46 \\
Aguda & $\mathbf{0 . 8 7 2}$ & $\mathbf{0 . 5 2 5}$ & - \\
\hline
\end{tabular}

reproductively inactive between December-January and June. Gametogenesis started in June, and sexual maturity steadily increased until September-October, when spawning occurred. There was no sign of re-ripening during the study period, and all gonads were spent by December-January.

\section{DISCUSSIDN}

The reproductive patterns obtained in the present study generally fit the latitudinal trend previously described for Patella and other intertidal species, consisting in progressively longer reproductive seasons and spawning occurring later in the year towards the south (Bowman \& Lewis, 1986; Lewis, 1986). This trend is particularly noticeable in Patella depressa and Patella ulyssiponensis, two species that show markedly seasonal breeding cycles at the northern part of the range, with summer spawning periods (e.g. Dodd, 1956; Orton \& Southward, 1961; Thompson, 1979; Bowman, 1985; Bowman \& Lewis, 1986; Delany et al., 2002; Moore et al., 2007; McCarthy et al., 2008), but on the other hand are capable of nearly continuous breeding in northern Portugal, with loose synchrony in gonad development and spawning. Reproductive cycles of Patella vulgata are much more synchronized throughout its range, and exhibit a marked seasonal trend, with well-defined breeding and resting periods. The most obvious change with latitude concerns the timing of spawning events, which tend to occur earlier in the northern part of the range. The main spawning period in
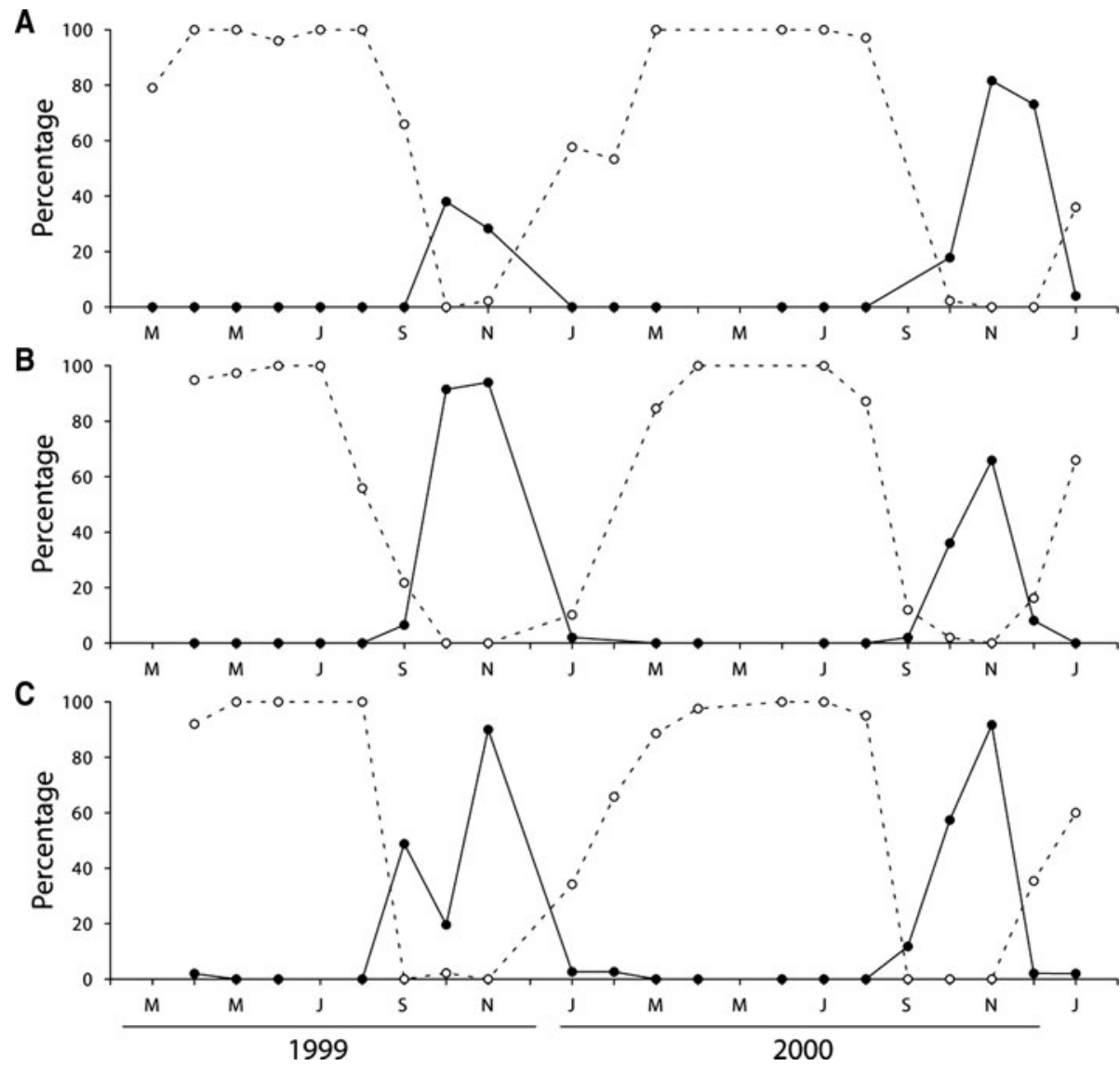

Fig. 3. Patella vulgata: percentage of gonads in undeveloped (neuter or Stage 1, dashed line) and advanced (gonad Stages 4 and 5 , full line) maturation state, between January 1999 and December 200o, at (A) Moledo do Minho, (B) Viana do Castelo and (C) Homem do Leme. 


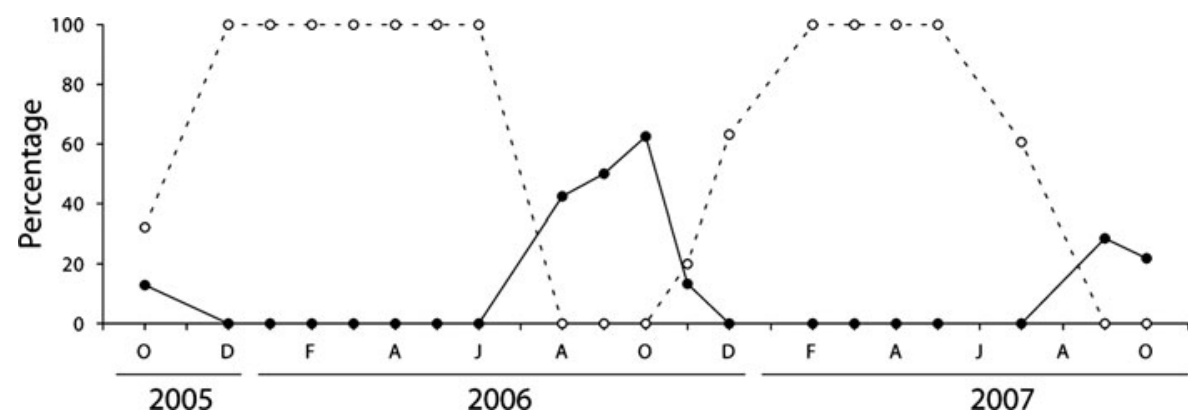

Fig. 4. Patella rustica: percentage of gonads in undeveloped (neuter or Stage 1, dashed line) and advanced (gonad Stages 4 and 5 , full line) maturation state, between October 2005 and October 2007, at Cabo Raso.

P. vulgata starts in September in northern Scotland (Baxter, 1982, 1983; Bowman \& Lewis, 1986) and also in north-eastern England (Bowman, 1985; Bowman \& Lewis, 1977, 1986), October-November in south-western Ireland (Thompson, 1980; McCarthy et al., 2008), November in south-western Britain (Evans, 1953; Orton et al., 1956; Bowman \& Lewis, 1986) and northern France (Fisher-Piètte, 1948; Choquet, 1966), and November-December in northern Spain (Ibañez et al., 1986; Othaitz, 1994) and northern Portugal (Guerra \& Gaudêncio, 1986; this study).

The present work provided the first description of the reproductive cycle of Patella rustica on the Portuguese coast. However, since it lacked spatial replication and encompassed roughly two reproductive seasons, results must be interpreted with caution. During the study period, this species was reproductively active between July and December, and only one spawning event seemed to occur in each season. These results do not differ much from observations from the Basque coast of Spain, where this species displays a very similar breeding cycle, although with evidence of multiple spawning events (Othaitz, 1994). In the Mediterranean, $P$. rustica has a longer breeding period, with less synchronous multiple spawnings occurring between August and November (Frenkiel, 1975; Othaitz, 1994).

The reproductive cycles of $P$. depressa, $P$. ulyssiponensis and $P$. vulgata showed general similarity with those previously reported by Guerra \& Gaudêncio (1986) for the northern Portuguese coast, although there were important differences. Guerra \& Gaudêncio (1986) suggested that $P$. depressa and $P$. ulyssiponensis displayed a bimodal breeding pattern, due to the occurrence of reproductive pauses in summer and winter. The present results did not support their assumption, since an obvious winter pause was never observed. On the other hand, in the case of $P$. vulgata, although the proportion of individuals with gonads in advanced stages of development remained similar, the duration of breeding cycles in 19992000 were consistently shorter than the ones reported at

Table 3. Patella vulgata: Pearson's correlation coefficient $(r)$ among locations, using the proportion of undeveloped (neuters and Stage 1, below diagonal) and full gonads (Stages 4 and 5, above diagonal). Significant values are in bold.

\begin{tabular}{llll}
\hline & $\begin{array}{l}\text { Moledo do } \\
\text { Minho }\end{array}$ & $\begin{array}{l}\text { Viana do } \\
\text { Castelo }\end{array}$ & $\begin{array}{l}\text { Homem do } \\
\text { Leme }\end{array}$ \\
\hline Moledo do Minho & - & 0.576 & 0.542 \\
Viana do Castelo & $\mathbf{0 . 9 0 4}$ & - & 0.737 \\
Homem do Leme & $\mathbf{0 . 8 9 1}$ & $\mathbf{0 . 9 4 3}$ & - \\
\hline
\end{tabular}

Moledo do Minho in the early 1980 s by Guerra \& Gaudêncio (1986). These authors observed development starting in July-August, with minor spawning taking place in September-October, the main spawning period taking place between November and January, and all gonads gradually emptying until May. In the present study, the onset of gonad activity was never observed before late AugustSeptember, whilst spawning took place between November and January, with all individuals entering the neuter state until the end of March. Another important difference resides in an apparently reduced ability of multiple spawning events during $P$. vulgata's breeding season. Multiple spawnings in $P$. vulgata have been observed in the UK (Blackmore, 1969; Bowman \& Lewis, 1977, 1986) and also in northern Spain (Othaitz, 1994). In northern Portugal, minor episodes of gamete release prior to the main spawning event were also recorded by Guerra \& Gaudêncio (1986). However, the present study suggests that they no longer occur with the same frequency.

Sea temperature has long been considered one of the most influential factors in controlling breeding in marine invertebrates (Orton, 1920; Olive, 1995). The observed changes in the breeding cycles of Patella spp. from the early 1980 s to the present might be related to the increase in seawater temperature estimated to occur along the Portuguese coast at a constant rate of $0.010^{\circ} \mathrm{C}_{\text {year }}{ }^{-1}$ (Lemos \& Pires, 2004). Moreover, average sea-surface temperature during winter months (December to March) in northern Portugal increased from $13.7^{\circ} \mathrm{C}$ for the period of $1981-1983$ to $14.5^{\circ} \mathrm{C}$ for $1998-$ 2000 (values derived from in situ raw data obtained from the International Comprehensive Ocean-Atmosphere Data Set; Woodruff et al., 1998). A possible consequence of this increase could be the disappearance of a potential inhibitory effect of extreme low winter temperatures on gonad development, thus allowing for continuous breeding from autumn to spring in $P$. depressa and $P$. ulyssiponensis. In the case of $P$. vulgata, which is close to its southern range limit (Fischer-Piètte \& Gaillard, 1959; Southward et al., 1995), increased winter temperatures are likely to have the opposite effect on gametogenesis. There is strong evidence of changes in the reproductive cycles of $P$. depressa and $P$. vulgata as far north as Great Britain, possibly driven by climate warming. In recent years, $P$. depressa has been spawning earlier and for longer periods, and there is also evidence of gonad re-ripening (Moore et al., 2007). This behaviour contrasts with the severe drop in spawning success of $P$. vulgata recently recorded at certain locations in south-western Britain, where only a small proportion of the populations 
reached advanced maturity stages at some locations near Plymouth (Moore et al., 2007). In the light of the present observations, it is likely that $P$. vulgata faces decreasing reproductive success also in Portugal. Further contraction of its annual spawning period could lead to growing decline in population size and connectivity at the southern end of the range. Similarly, $P$. rustica which is near its northern range limit (Fischer-Piètte \& Gaillard, 1959; Lima et al., 2007) only spawns once, in contrast to the warmer Mediterranean and the Basque coast. However, the rising trend in seawater temperature along the Portuguese coast will favour the increase of the species' reproductive potential, thus contributing to its expansion.

The sampling scheme adopted in this work does not allow investigating a possible role of environmental cues in the observed spawning patterns. However, the variability observed in the frequency and timing of spawning events in $P$. depressa and $P$. ulyssiponensis, both among years and locations, suggests a possible role of stochastic events in stimulating gamete release as soon as a certain level of gonad maturity is reached at a local scale. The same type of cues may also be involved in the induction of spawning in $P$. vulgata and $P$. rustica. However, the short time window suitable for breeding in these two species probably does not allow for gonad re-development in most seasons. A number of studies carried out in the UK (Orton et al., 1956; Orton \& Southward, 1961; Thompson, 1979) suggest that spawning in Patella spp. is frequently associated with strong onshore winds and high wave action. Orton \& Southward (1961) argued that air temperature was also a possible stimulus for spawning in $P$. depressa. Several studies conducted for $P$. vulgata suggested that spawning was not only associated with rough seas, but also with a drop in seawater temperature below $12^{\circ} \mathrm{C}$ (Bowman, 1985; Bowman \& Lewis, 1977, 1986; Delany et al., 2002). However, the large time gaps between samples did not allow the establishment of an unequivocal correspondence between periods of rough sea and spawning events. More recently, Le Quesne (2005) used high-frequency observations of gonad condition, wave action and water temperature to confirm this relationship by pinpointing main spawning events in $P$. vulgata to periods of high wave action, associated with a drop in sea temperature. Although lacking empirical evidence, it also appears to be the case in northern Portugal. However, the $12^{\circ} \mathrm{C}$ threshold is probably not applicable throughout the geographical range of P. vulgata (Bowman, 1985), and higher sea temperatures might be involved in stimulating spawning in northern Portuguese $P$. vulgata populations.

\section{ACKNOWLEDGEMENTS}

P.A. Ribeiro was funded by a FCT doctoral grant reference SFRH/BD/8232/2002. S.J. Hawkins was funded by a NERC funded Fellowship to the Marine Biological Association of the United Kingdom and the Oceans 2025 Programme.

\section{REFERENCES}

Baxter J.M. (1982) Population dynamics of Patella vulgata in Orkney. Netherlands Journal of Sea Research 16, 96-104.
Baxter J.M. (1983) Annual variations in soft-body dry weight, reproductive cycle and sex ratios in populations of Patella vulgata at adjacent sites in the Orkney Islands. Marine Biology 76, 149-157.

Blackmore D.T. (1969) Studies of Patella vulgata L. I. Growth, reproduction and zonal distribution. Journal of Experimental Marine Biology and Ecology 3, 200-213.

Bowman R.S. (1985) The biology of the limpet Patella vulgata L. in the British Isles: spawning time as a factor determining recruitment success. In Moore P.G and Seed R. (eds) The ecology of rocky coasts. New York: Columbia University Press, pp. 178-193.

Bowman R.S. and Lewis J.R. (1977) Annual fluctuations in the recruitment of Patella vulgata L. Journal of the Marine Biological Association of the United Kingdom 7, 793-815.

Bowman R.S. and Lewis J.R. (1986) Geographical variation in the breeding cycles and recruitment of Patella spp. Hydrobiologia 142, $41-56$.

Branch G.M. (1981) The biology of limpets: physical factors, energy flow and ecological interactions. Oceanography and Marine Biology: an Annual Review 19, 235-380.

Brazão S., Boaventura D., Morais S., Narciso L. and Ré P. (2003) Reproduction of Patella depressa Pennant, 1777 on the central Portuguese coast. Boletín del Instituto Español de Oceanografía 19, 453-460.

Choquet M. (1966) Biologie de Patella vulgata L. dans le Boulonnais. Cahiers de Biologie Marine 7, 1-22.

Delany J., McGrath D., O'Riordan R. and Myers A. (2002) Reproduction in the intertidal limpets Patella vulgata and Patella ulyssiponensis. In Myers A. (ed.) New survey of Clare Island, Volume 3. Marine intertidal ecology. Dublin: Royal Irish Academy, pp. $91-116$

Dodd J.M. (1956) Studies on the biology of limpets. III. Hermaphroditism in the three British species of Patella. Journal of the Marine Biological Association of the United Kingdom 35, 327-340.

Evans R.G. (1953) Studies on the biology of the British limpets-the genus Patella on the south coast of England. Proceedings of the Zoological Society of London 123, 357-376.

Fischer-Piètte E. (1948) Sur les éléments de prospérité des Patelles et sur leur spécificité. Journal de Conchyliologie 88, 45-96.

Fischer-Piètte E. and Gaillard J.-M. (1959) Les Patelles, au long des côtes Atlantiques Ibériques et Nord-Marocaines. Journal de Conchyliologie 99, 135-200.

Frenkiel L. (1975) Contribution à l'étude des cycles de reproduction des Patellidae en Algèrie. Pubblicazioni della Stazione Zoologica di Napoli 39, 153-189.

Guerra M.T. and Gaudêncio M.J. (1986) Aspects of the ecology of Patella spp. on the Portuguese coast. Hydrobiologia 142, 57-69.

Ibañez M., Peña J. and Feliu J. (1986) Reproduction of Patella spp. on the Basque coast of Spain. Hydrobiologia 142, 237.

Lemos R.T. and Pires H.O. (2004) The upwelling regime off the west Portuguese coast, 1941-2000. International Journal of Climatology $24,511-524$

Le Quesne W.J.F. (2005) The response of a protandrous species to exploitation, and the implications for management: a case study with patellid limpets. PhD thesis. University of Southampton, Southampton, United Kingdom.

Lewis J.R. (1986) Latitudinal trends in reproduction, recruitment and population characteristics of some rocky littoral molluscs and cirripedes. Hydrobiologia 142, 1-13. 
Lima F.P., Queiroz N., Ribeiro P.A., Hawkins S.J. and Santos A.M. (2006) Recent changes in the distribution of a marine gastropod Patella rustica Linnaeus, 1758 , and their relationship to unusual climatic events. Journal of Biogeography 33, 812-822.

Lima F.P., Ribeiro P.A., Queiroz N., Xavier R., Tarroso P., Hawkins S.J. and Santos A.M. (2007) Modelling past and present geographical distribution of the marine gastropod Patella rustica as a tool for exploring responses to environmental change. Global Change Biology 13, 20652077.

McCarthy M., Woosnam P. and Culloty S.C. (2008) Histological investigation of the reproductive cycles of the limpets Patella vulgata and Patella ulyssiponensis. Marine Biology 153, 871-877.

Moore P., Thompson R.C. and Hawkins S.J. (2007) Effects of grazer identity on the probability of escapes by a canopy-forming macroalga. Journal of Experimental Marine Biology and Ecology 344, 170-180.

Olive P.J.W. (1995) Annual breeding cycles in marine invertebrates and environmental temperature: probing the proximate and ultimate causes of reproductive synchrony. Journal of Thermal Biology 20, 79-90.

Orton J.H. (1920) Sea temperature, breeding and distribution in marine animals. Journal of the Marine Biological Association of the United Kingdom 12, 339-366.

Orton J.H. and Southward A.J. (1961) Studies on the biology of limpets. IV. The breeding of Patella depressa Pennant on the north Cornish coast. Journal of the Marine Biological Association of the United Kingdom 41, 653-662.

Orton J.H., Southward A.J. and Dodd J.M. (1956) Studies on the biology of limpets. II. The breeding of Patella vulgata L. in Britain. Journal of the Marine Biological Association of the United Kingdom 35, 149-176.
Othaitz J.P. (1994) Estudio de los ciclos reproductores de cuatro species de lapas y dos de tróquidos (Gastropoda, Prosobranchia) del piso intermareal de la costa Vasca. PhD thesis. Universidad Autónoma de Madrid, Madrid, Spain.

Southward A.J., Hawkins S.J. and Burrows M.T. (1995) Seventy years' observations of changes in distribution and abundance of zooplankton and intertidal organisms in the western English Channel in relation to rising sea temperature. Journal of Thermal Biology 20, 127-155.

Thompson G.B. (1979) Distribution and population dynamics of the limpet Patella aspera (Lamarck) in Bantry Bay. Journal of Experimental Marine Biology and Ecology 40, 115-135.

Thompson G.B. (1980) Distribution and population dynamics of the limpet Patella vulgata in Bantry Bay. Journal of Experimental Marine Biology and Ecology 45, 173-217.

and

Woodruff S.D., Diaz H.F., Elms J.D. and Worley S.J. (1998) COADS release 2 data and metadata enhancements for improvements of marine surface flux fields. Physics and Chemistry of the Earth 23, $517-526$.

\section{Correspondence should be addressed to:} P.A. Ribeiro CIBIO, Centro de Investigação em Biodiversidade e Recursos Genéticos, Campus Agrário de Vairão, 4485-661 Vairão, Portugal email: paribeir@fc.up.pt 